\title{
Relict structure in saprolite - a case study
}

\author{
L McKenzie Pells Sullivan Meynink, Australia
}

\begin{abstract}
This paper presents a case study where relict structure in saprolite has contributed to ongoing instability of a slope within an operational open pit mine. The study provides the pre-mining structural understanding, discusses slope performance, including key factors contributing to instability, and examines the current structural model. The paper shows that structural patterns within bedrock also occur in the saprolite. It highlights that, although it is difficult to obtain data on relict structure using borehole methods, slope failure due to relict structure should be recognised because it does occur. Design uncertainty and risks associated with this type of instability needs to be identified in the early stages of the mine planning process.
\end{abstract}

\section{Introduction}

Saprolite is the term commonly applied to the zone of soil-like material, which retains the relict rock structure (Deere \& Patton 1971) that occurs within a lateritic weathering profile and is derived by the in situ weathering and decomposition of rock under sub-tropical and tropical climatic conditions. In this paper, saprolite refers to the horizon comprising extremely weathered, highly weathered and moderately weathered rock units based on the ISRM (1981) weathering classification.

Saprolite material is a very special type of soil, whose strengths and other characteristics are closely related to the relict structures present in the original rock (Deere \& Patton 1971). These relict structures undergo a weakening process during weathering (Aydin 2006) and typically have infills with very low shear strengths, such as clay.

At the design stage of a project relict structure in saprolite is often overlooked as a control for stability in open pit slopes. One of the main reasons for this is that identification, sampling and testing of relict structures can be difficult in borehole core. In addition, assessing shear strength of relict structures and pore water pressures along these structures is also very difficult. It is not until the operational stage when slopes experience instability that the influence of these structures on slope stability are realised.

All orientations stated in this paper are referenced to mine grid.

\section{Geological setting}

\subsection{Regional geology}

The mine is in a major Australian fold belt of early Proterozoic age. The fold belt, which comprises a complex association of sedimentary, volcanic and intrusive rock of early Cambrian to Devonian age, is interpreted to have formed in a geological environment akin to modern southwest Pacific oceanic arc and back arc basin environments (Fergusson 2003).

The fold belt represents multiple periods of deformation and has structural trends mainly striking north-south with west dipping thrust faults intermixed with tightly folded bedding.

\subsection{Local geology}

Figure 1 shows the bedrock geology of the mine area, and the location and dates of instabilities that occurred in the west wall and bullnose design configuration. Figure 2 is a geological schematic east-west cross-section. 


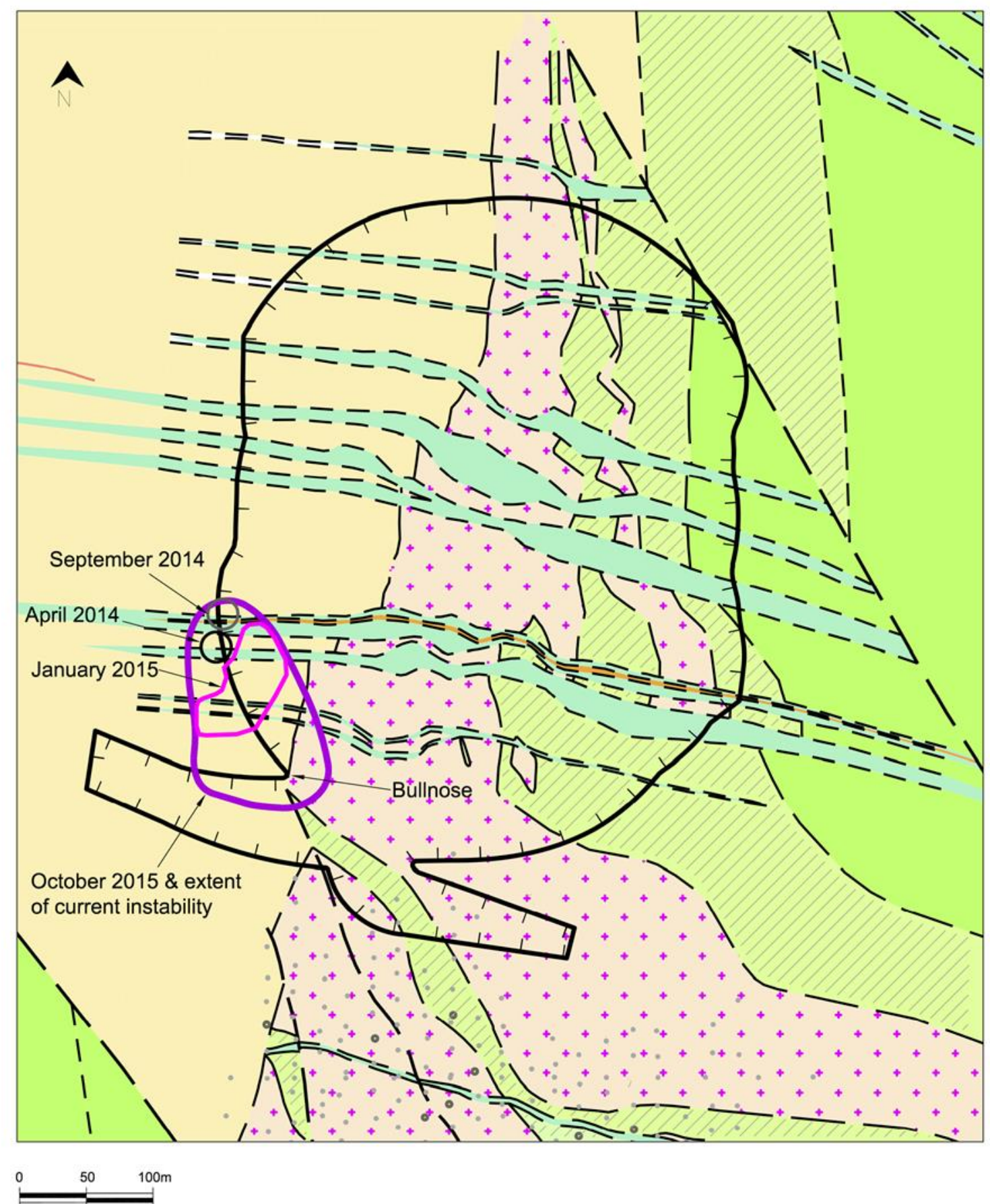

LEGEND

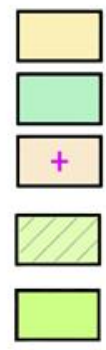

Siltstone, sandstone, conglomerate

Fault, inferred

Dolerite

son Shear Zone

Feldspar porphyry

Undifferentiated volcaniclastic sediments

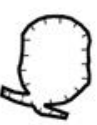

Geological boundary,

inferred

Volcanics and volcaniclastics

Figure 1 Bedrock geology of the mine area and locations and dates of instabilities 


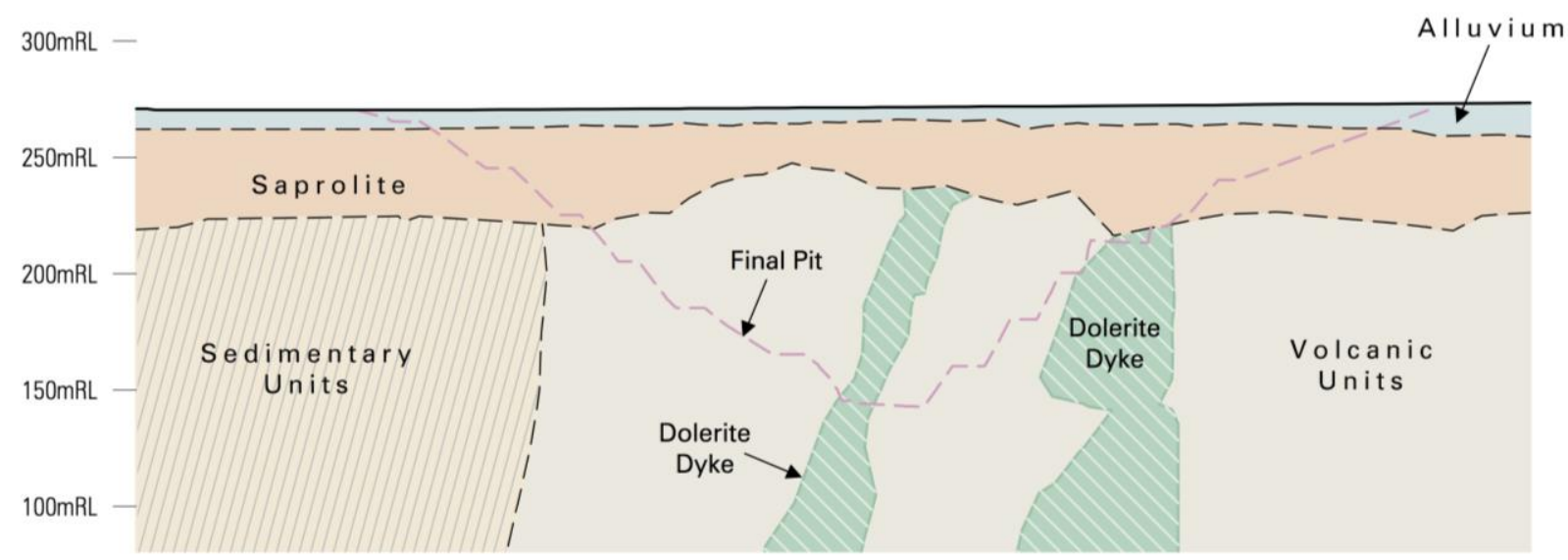

Figure 2 Schematic east-west cross-section showing geology through the mine area

The bedrock geology comprises a unit of volcaniclastic sediments, lavas and intrusive porphyritic rocks overlain in the west by a sedimentary package of bedded siltstones, conglomerates and sandstones. The contact between the volcanic and sedimentary units is interpreted as a fault striking north-south with a moderate to steep dip to the west. Narrow dykes of mainly doleritic composition intrude both the volcanics and sedimentary units. The dykes strike east-west and have a steep dip.

Lateritic weathering, and weathering to saprolite, possibly occurred during the late Palaeozoic. The depth of weathering reaches $50 \mathrm{~m}$ and forms an irregular mantle over fresh rock.

The entire mine area is covered by Quaternary and Tertiary age alluvium comprising sandy clays, sandy silts and clayey sands. The alluvium is up to $15 \mathrm{~m}$ thick in the study area.

Bedding within the sedimentary units and the feldspar porphyry and volcaniclastics units strike roughly north-south. Towards the southern end of the mine there is a slight rotation in this orientation to a northwest/southeast strike, possibly a result of dextral strike slip movement on a significant northwest striking fault further to the south. Although not abundant, faults trending northwest with a steep dip occur, in addition to some with a shallow east to northeast dip.

\section{Design history}

The author was not involved in the provision of the original pit slope design for slopes in saprolite. Design in the alluvium and saprolite was assessed based on the results of limit equilibrium analyses assuming circular failure through both horizons. Strengths for the saprolite and alluvium horizons were interpreted from laboratory testing. A continuous overall slope angle was used for the various pit slope aspects to achieve a Factor of Safety of 1.2. Analyses assumed dry conditions. Inter-ramp angles through alluvium and saprolite varied from 35 to $42^{\circ}$. The proposed inter-ramp design for the slopes that experienced instabilities was about $39^{\circ}$ using $20 \mathrm{~m}$ high benches, $5 \mathrm{~m}$ berm widths and $45^{\circ}$ bench angles.

\section{$4 \quad$ Understanding of structure pre-mining}

Borehole drilling for feasibility stage design work did not collect any data on structure in the saprolite, this was mainly due to difficulties with core orientation.

Figure 3 is a stereographic projection (stereoplot) presenting structural data and assessed structural sets relevant to the west wall and bullnose stability and is from borehole structural data from the slightly weathered to fresh sedimentary unit. Four joint sets with mean dip and dip directions of, $85^{\circ} / 252^{\circ}$ (JN1), $78^{\circ} / 036^{\circ}$ (JN2) and $53^{\circ} / 076^{\circ}$ (JN3) and $20^{\circ} / 293^{\circ}$ (JN4), were assessed. While these joint sets were defined 
at the feasibility stage, a small number of scattered joints with shallow dips towards the east, northeast and north are evident in Figure 3. These joints have similar orientations to the relict structures attributed to the instabilities in the saprolite horizon. No shears or faults were identified at the feasibility stage.

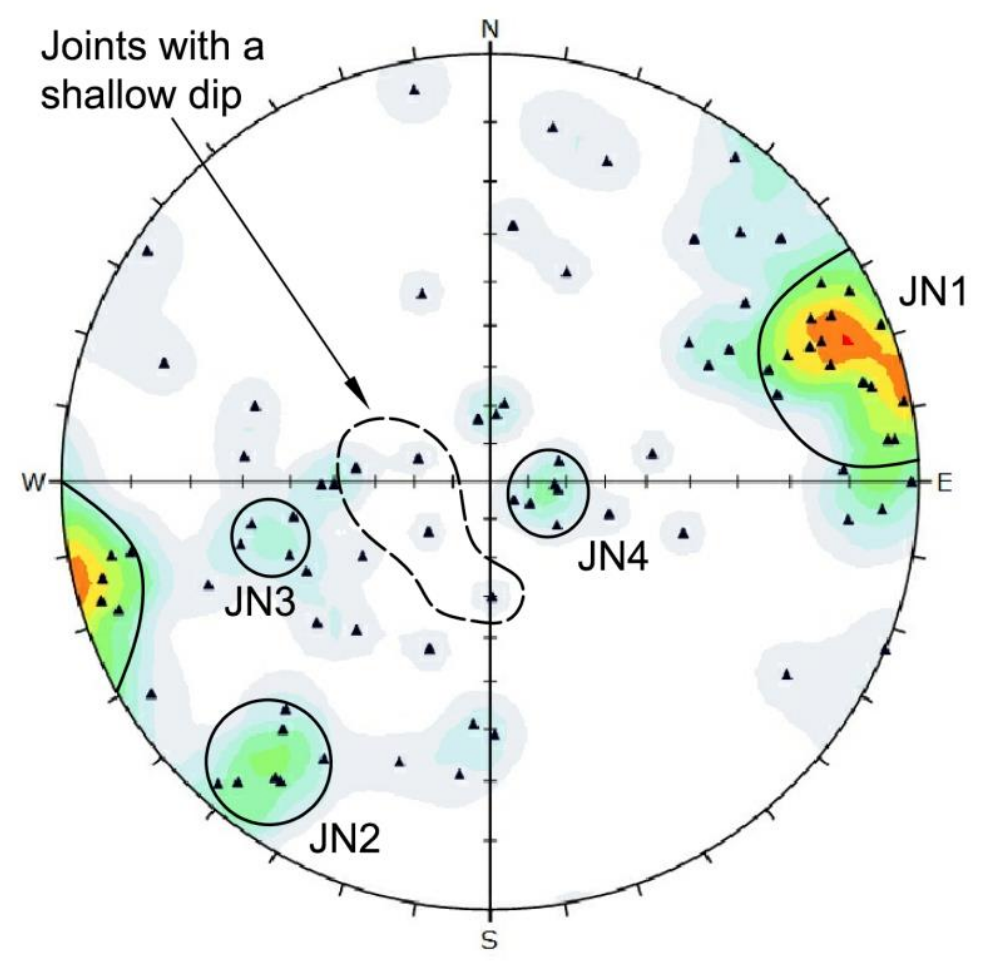

Figure 3 Stereoplot (equal angle) of borehole data and assessed structural sets in the sedimentary unit

The structural data is from boreholes drilled primarily to collect exploration data but geotechnical data was also obtained. Typically data from boreholes with a dual purpose is less than optimal as the data required to assess the characteristics of materials is often not collected.

\section{$5 \quad$ History of slope instability}

Instability occurred in four distinct events as detailed on Figure 1. An initial failure occurred in April 2014 when the pit was in its early stage of development and when $15 \mathrm{~m}$ of slope was exposed (the upper $8 \mathrm{~m}$ comprising alluvium and the lower $7 \mathrm{~m}$ saprolite). The September 2014 failure occurred as the slope height increased to $25 \mathrm{~m}$ and affected part of a remediated slope. Instability progressed towards the south and to the northern end of the bullnose in January 2015 and into the bullnose design configuration in October 2015 (Figure 4) when structures in the moderately weathered saprolitic profile were exposed through mining. The current instability involves a portion of slope $160 \mathrm{~m}$ long and $50 \mathrm{~m}$ high with overall wall angles of between $30^{\circ}$ at the northern end to $35^{\circ}$ at its southern (Figure 5). 


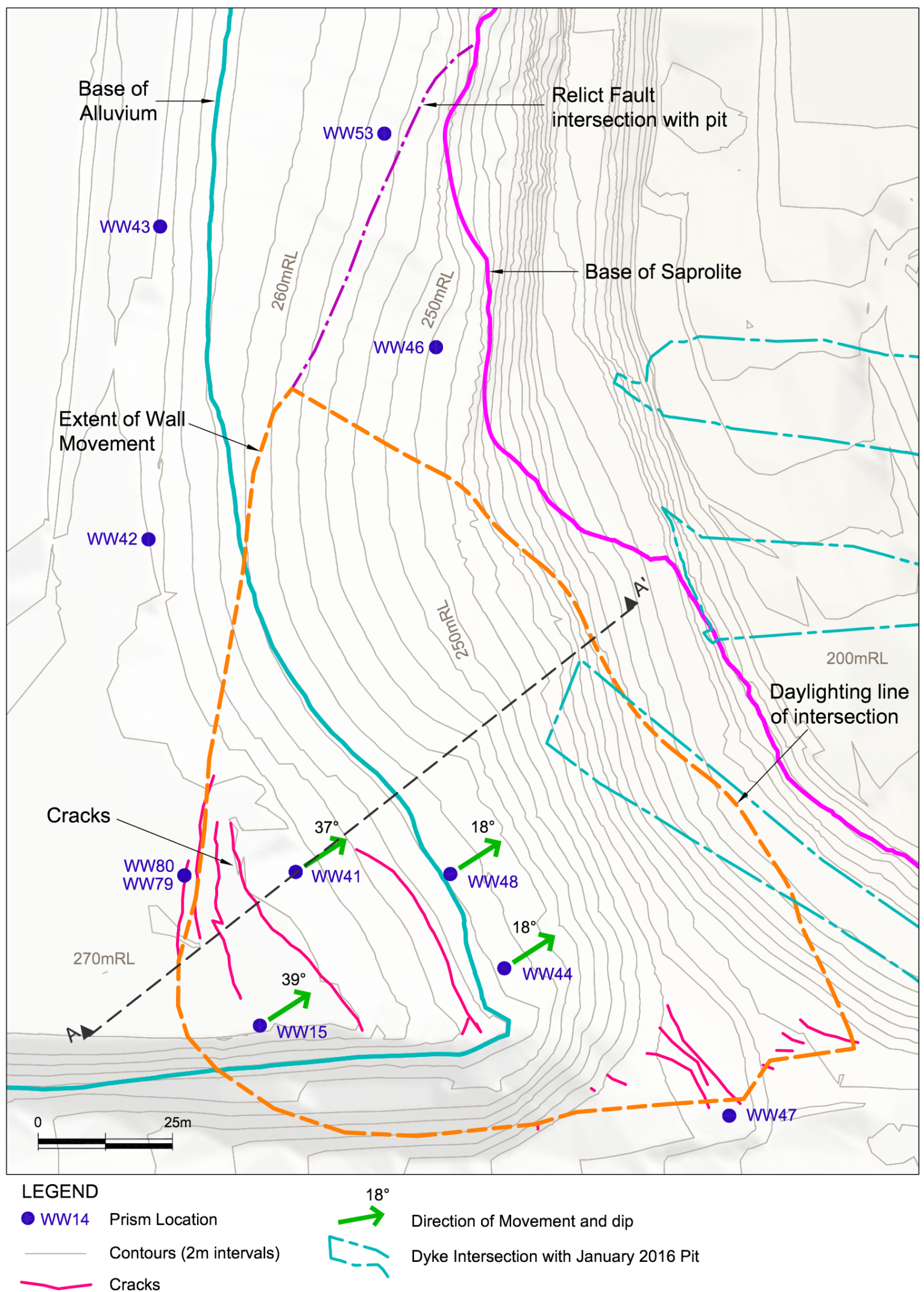

Figure 4 Pit plan showing extent of current instability and prism movement and dip 


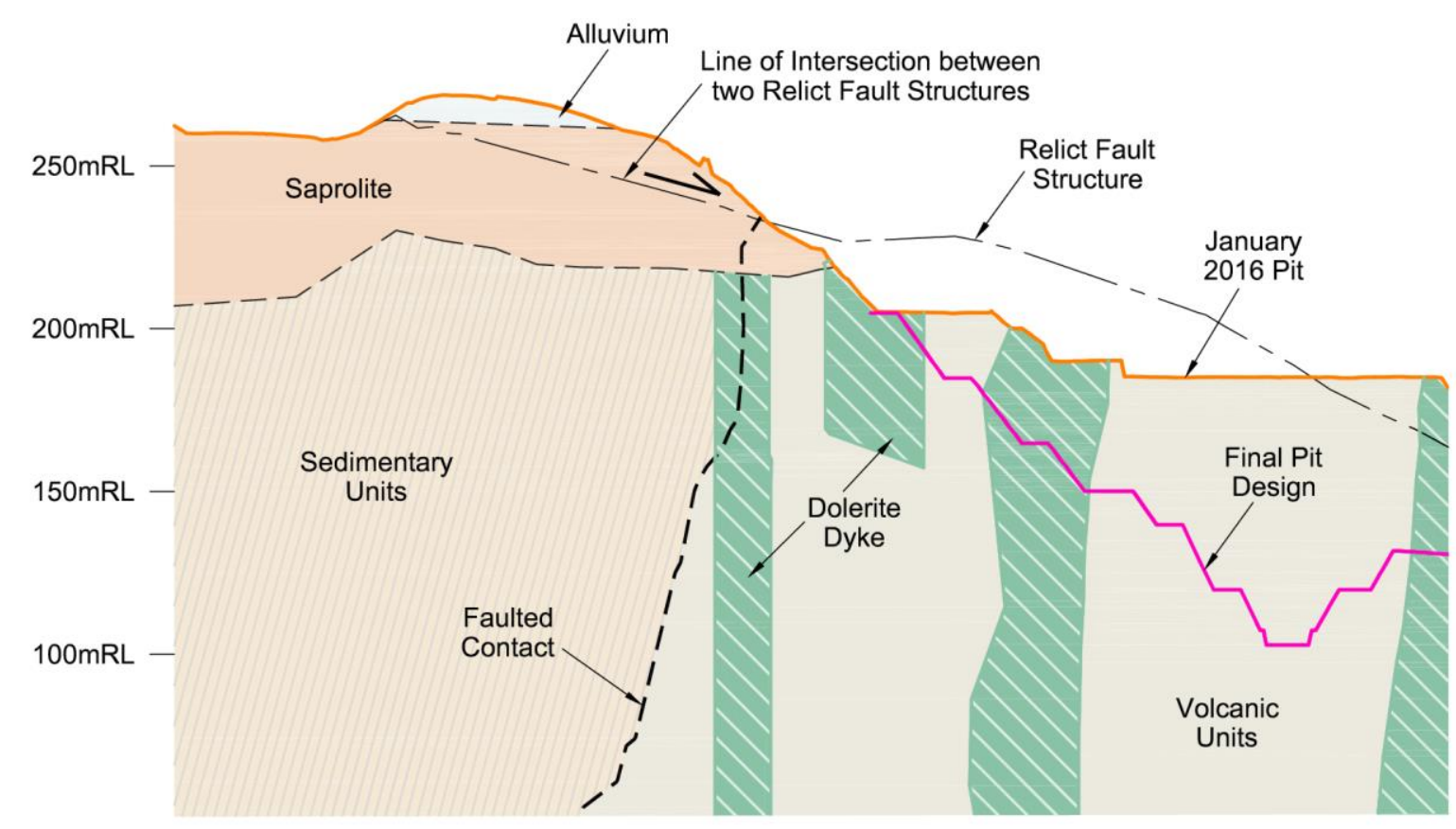

Figure 5 Cross-section AA' showing relict fault feature, geology, as built January 2016 pit and final pit design

The main contributor to instability is movement along structures in the saprolite that dip at shallow angles into the pit (Figure 5). Evidence that instability is structurally controlled include, style of cracks and their orientation, geometry of failures/instability, direction and dip of wall movements based on prism monitoring data (Figure 4), and presence of a few structures that dip at a shallow angle in-pit within the saprolite that have clay in-fill.

A continuous fault with an orientation of $21^{\circ} / 100^{\circ}$ was exposed in the moderately weathered saprolitic zone in October 2015. Instability in the west wall is attributed to planar sliding along this feature in the saprolitic zone. In-pit mapping within the slightly weathered and fresh rock mass and a review of the geological model identified the fault to be a significant thrust fault, which displaces all geological units by up to $40 \mathrm{~m}$ vertically and has a strike length of greater than $500 \mathrm{~m}$. In addition, a continuous fault with orientation of $20^{\circ} / 020^{\circ}$ forms a wedge with this fault to daylight in the bullnose. Prism monitoring since instability began in the bullnose in October 2015 provides a sense of wall movement direction and dip, these results are shown in Figure 4. The results appear to confirm that the relict structures exposed are attributing to wall movement with their line of intersection having a similar orientation to wall movement as indicated by prism monitoring. Prisms have proven to be a useful wall monitoring tool, this is in contrast to radar where the direction and dip of wall movement cannot be resolved.

Other key contributing factors to the instabilities are:

- Rainfall: Figure 6 suggests that the build-up of water pressures promoted sliding, this is especially evident in January 2015 when $77 \mathrm{~mm}$ of rain fell over a ten day period.

- Lithology: movement is initiated in the saprolite where the parent rock type is typically sedimentary but is also associated with dolerite dykes, the dykes possibly influence ground water pressures. The low strength clays produce by the lateritic weathering of the mafic minerals have also contributed to failure.

- Mining activity: increased slope height in saprolite and the daylighting of the continuous relict fault features. 


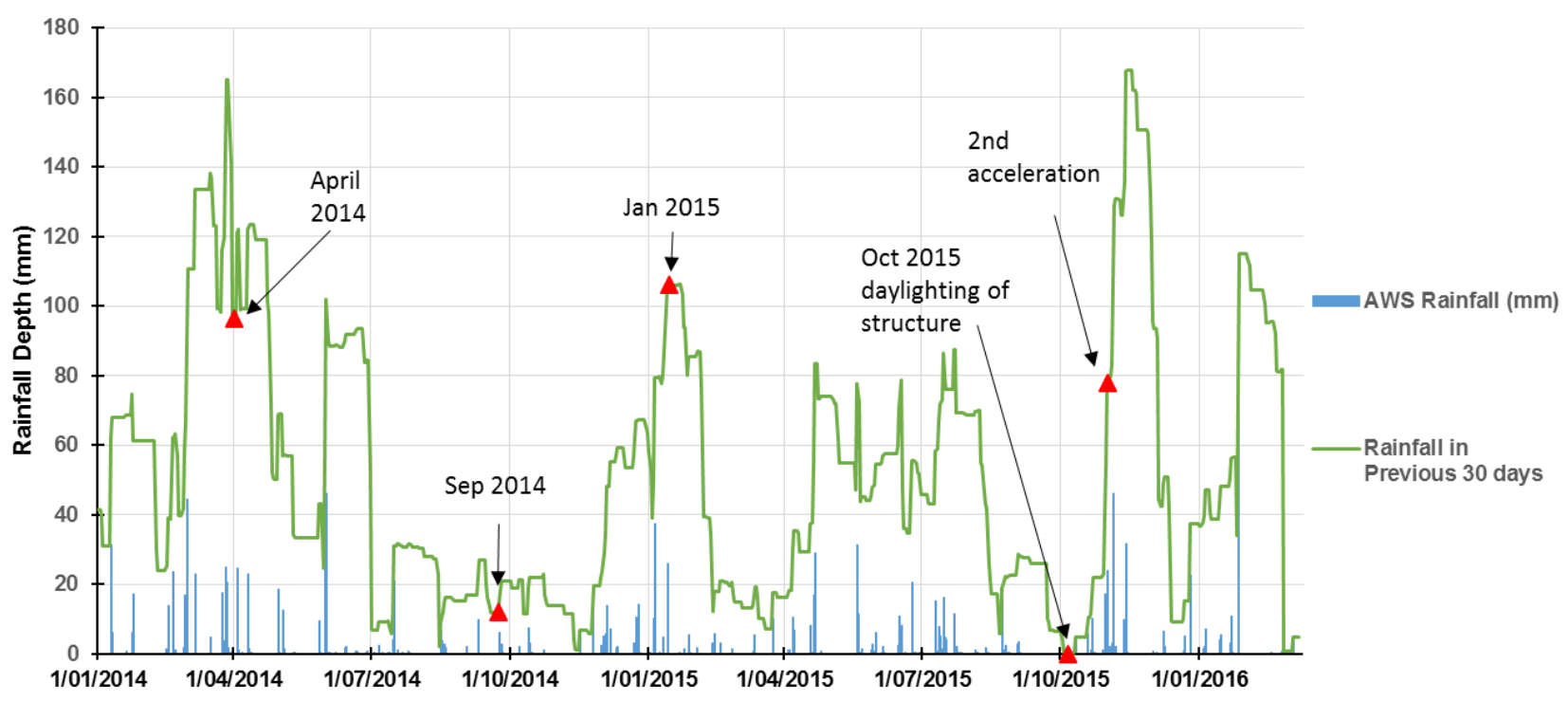

Figure 6 Plot of rainfall from January 2014 to January 2016 showing date of key instability events

\section{Current structural model}

Figure 7 is a stereoplot presenting major structures mapped in the west wall and bullnose slopes as exposed during mining, i.e. in-pit mapping data. Major structures in this paper are structures with mapped lengths of $15 \mathrm{~m}$ and greater and, therefore, potentially impact on slope stability at the inter-ramp scale. Most of the data is from mapping of the slightly weathered and fresh rock with only a minor amount from highly and moderately weathered rock. This is due to structure being typically less preserved through these latter zones.

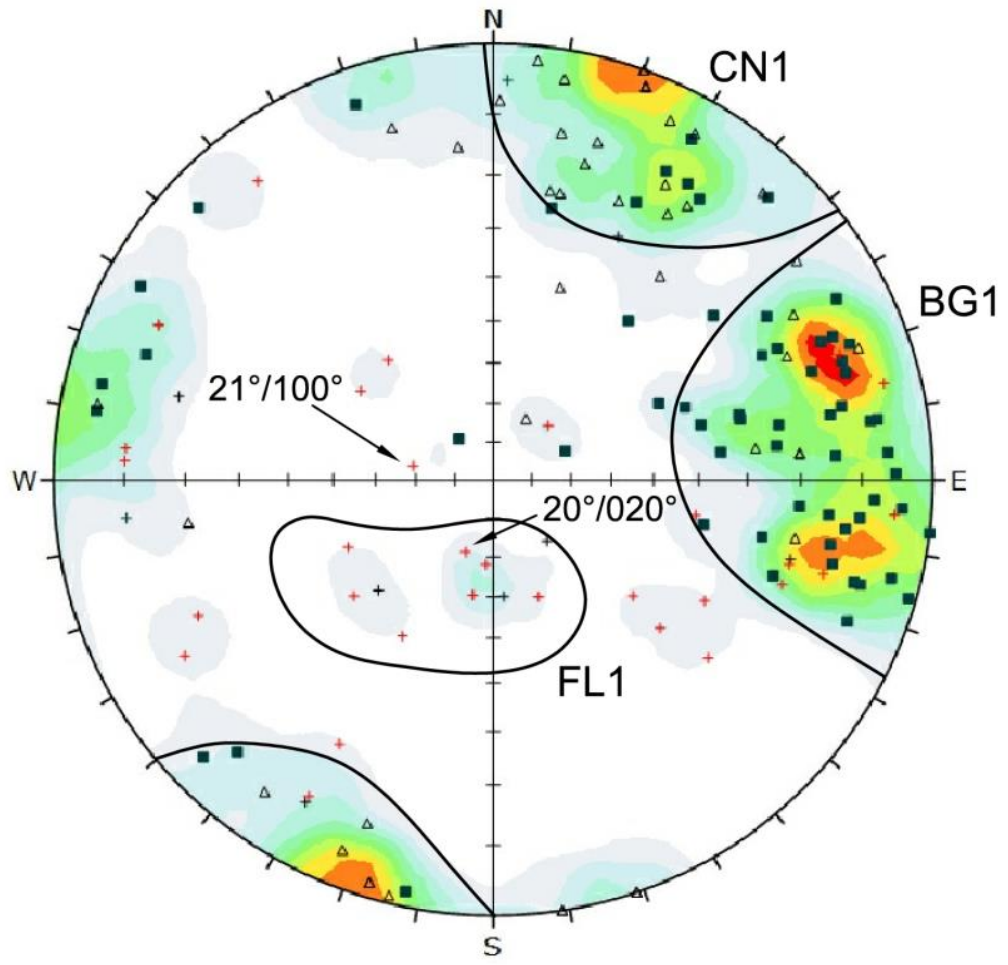

Figure 7 Stereoplot (equal angle) of in-pit mapping data and assessed major structural sets in the sedimentary unit 
The dip and dip direction of the assessed major sets are bedding $74^{\circ} / 265^{\circ}$ (BG1), dolerite dyke contacts $85^{\circ} / 206^{\circ}$ (CN1) and a fault set $31^{\circ} / 025^{\circ}$ (FL1). The continuous faults/shears that dip at a shallow angle towards the north and northeast (FL1) can be attributed to the instabilities in the saprolite horizon. The two faults with dip/dip directions of $21^{\circ} / 100^{\circ}$ and $20^{\circ} / 020^{\circ}$ and form a wedge in the bullnose are also identified on Figure 7.

A comparison between the in-pit mapping stereoplot (Figure 7) and the pre-mining stereoplot (Figure 3) highlights the limitations of borehole data to assess structure continuity. Joint defects, as identified in the boreholes, are typically assumed to have a limited length and affect design at a bench scale, whereas faults and shears typically have longer lengths and affect design at the inter-ramp scale.

\section{Conclusion}

The case study shows that instability in saprolite, due to relict structure, does occur and at a scale that has an impact on mining operations. Slope designers should recognise and consider relict structure in slope stability assessment even though identification, sampling and testing of relict structure is difficult using borehole drilling methods.

Slope performance and structural data in the slightly weathered and fresh rock, indicate that structural patterns in the bedrock extend into the saprolite horizon. Typically these relict structures have low shear strengths due to clay in-fill. At feasibility stage, investigations should be designed to collect relevant data to appropriately characterise relict structure in saprolite. Accepting that, with traditional site investigation methods, collection of this data may be difficult and, as such, designers could use bedrock structural patterns in slope stability assessment. Risks during mining can be mitigated through ongoing mapping and development of the geotechnical model.

This paper indicates that elevated water pressure in saprolitic can be a key trigger to slope failure and movement. Early planning and implementation of good surface water management to reduce water inflow into the slope during mining is important.

\section{Acknowledgement}

This case study is based on a real operation, which has not been named. The author thanks the organisation for their assistance and support in preparing this paper.

\section{References}

Aydin, A 2006, 'Stability of saprolitic slopes: nature and role of field scale heterogeneities', Natural Hazards and Earth System Science, vol. 6, pp. 89-96.

Deere, DU \& Patton, FD 1971, 'Slope stability in residual soil slopes', in Proceedings of the 4th Panamerican Conference on Soil Mechanics and Engineering Foundation, American Society of Engineers, New York, no. 1, pp. 87-170.

Fergusson, CL 2003, 'Ordovician-Silurian accretion tectonics of the Lachlan Fold Belt, southeastern Australia', Australian Journal of Earth Sciences, vol. 50, pp. 475-490.

ISRM (International Society of Rock Mechanics) 1981, Rock Characterization, Testing and Monitoring: ISRM Suggested Methods, ET Brown (ed.), Pergamon Press, Oxford. 